\title{
Decrease in Hemoglobin Levels Following Surgery Influences the Outcome in Head and Neck Cancer Patients Treated with Accelerated Postoperative Radiotherapy
}

\author{
Berrin Pehlivan, $\mathrm{MD}^{1}$, Abderrahim Zouhair, $\mathrm{MD}^{1}$, François Luthi, $\mathrm{MD}^{2}$, Luc Bron, $\mathrm{MD}^{3}$, Philippe Pasche, $\mathrm{MD}^{3}$, \\ Daniela Dragusanu, MD', David Azria, MD, PhD $^{1}$, Oscar Matzinger, MD ${ }^{1}$, René O. Mirimanoff, MD ${ }^{1}$, and \\ Mahmut Ozsahin, MD, PhD ${ }^{1}$ \\ ${ }^{1}$ Radiation Oncology, University Hospital Center, University of Lausanne, Lausanne, Switzerland; ${ }^{2}$ Medical Oncology, \\ University Hospital Center, University of Lausanne, Lausanne, Switzerland; ${ }^{3}$ Otolaryngology-Head and Neck Surgery, \\ University Hospital Center, University of Lausanne, Lausanne, Switzerland
}

\begin{abstract}
Aim. To assess the influence of hemoglobin $(\mathrm{Hb})$ levels in locally advanced head and neck cancer (LAHNC) patients treated with surgery and postoperative radiotherapy (PORT).

Material and Methods. Pre- and postoperative Hb levels were collected in 79 patients treated with surgery followed by accelerated PORT for LAHNC. Median follow-up was 52 months (range 12-95 months).

Results and Discussion. Four-year overall survival (OS) rate was $51 \%$. Neither pre- nor postoperative $\mathrm{Hb}$ level ( $<120$ or $130 \mathrm{~g} / \mathrm{l}$ in women or men, respectively) influenced the outcome. However, when $\mathrm{Hb}$ decrease between pre- and postoperative $\mathrm{Hb}$ values was taken into account, 4year OS was significantly higher in patients with $\mathrm{Hb}$ difference less than $38 \mathrm{~g} / \mathrm{l}$ (quartile value) compared with those with $\mathrm{Hb}$ decrease $38 \mathrm{~g} / \mathrm{l}$ or more (61\% versus $16 \%$, $P=0.008)$.

Conclusion. Decrease in $\mathrm{Hb}$ level by more than $38 \mathrm{~g} / \mathrm{l}$ after surgery secondary to blood loss influences the outcome when postoperative RT is indicated.
\end{abstract}

Berrin Pehlivan and Abderrahim Zouhair contributed equally to this work.

Presented in part at the 6th International Conference on Head and Neck Cancer, August 7-11, 2004, Washington, DC.

(C) Society of Surgical Oncology 2009

First Received: 10 July 2008;

Published Online: 14 February 2009

M. Ozsahin, $\mathrm{MD}, \mathrm{PhD}$

e-mail: mahmut.ozsahin@chuv.ch
Despite the various strategies tried to improve the outcome, locoregional failure is still high in locally advanced head and neck cancer patients (LAHNC). Tumor stage, lymph node involvement, and extranodal extension (ENE) are well-known prognostic factors. Moreover, numerous studies pointed out that low hemoglobin $(\mathrm{Hb})$ levels before and during radiation therapy (RT) were associated with worse local control and survival in the various types of cancer. ${ }^{1-3}$

Head and neck cancer patients are at high risk for developing anemia. Extensive radical surgery, being one of the important reasons, may cause high intraoperative blood loss. Furthermore, multimodality therapy such as concomitant chemo- and RT, which improve patient survival, can worsen debilitating anemia. Direct association between tumor hypoxia and anemia is unclear, but anemia leads to decreased cell oxygenation and has been shown to contribute to tumor resistance to $\mathrm{RT}$ or chemotherapy via deprivation of the oxygen essential for the cytotoxic actions of these agents. ${ }^{4}$ Most studies report on the prognostic importance of the Hb level after primary RT with or without chemotherapy. ${ }^{5-7}$ However, there is no published study assessing the role of decreasing $\mathrm{Hb}$ because of blood loss during surgery on the outcome when postoperative RT (PORT) is indicated.

Herein, we report the influence of pre- and postoperative $\mathrm{Hb}$ levels, and the amount of its decrease, in LAHNC patients treated with surgery and PORT.

\section{PATIENTS AND METHODS}

Between December 1997 and June 2002, 79 consecutive patients treated with curative surgery followed by 
accelerated PORT were included in this retrospective study. Inclusion criteria consisted of nonmetastatic head and neck cancer classified pT1-pT4 and/or pN0-pN3, age 18 years or older, no previous history of cancer other than nonmelanoma skin cancer or in situ cervix cancer, and good performance status World Health Organization (WHO) scale 0-1 Patients with gross residual disease after surgery, previous RT with or without systemic chemotherapy, metastatic disease or known cause of anemia were excluded. The majority of patients were male (male-tofemale ratio 62/17). Median age was 60 years (range 3681 years). Patient characteristics are listed in Table 1.

All patients were seen and discussed at our multidisciplinary tumor board, and the treatment recommendation was made jointly by head and neck surgeon, radiation oncologist, and medical oncologist with advice from the pathologist, diagnostic radiologist, nursing staff, nutritionists, and dentists. Percutaneous endoscopic gastrostomy (PEG) was placed before or at the beginning of treatment in 24 of 79 patients $(30 \%)$, and 6 patients $(8 \%)$ required nasogastric feeding tube during their treatment.

TABLE 1 Characteristics of 79 patients

\begin{tabular}{|c|c|c|}
\hline & Number & $\%$ \\
\hline \multicolumn{3}{|l|}{ Tumor site } \\
\hline Oral cavity & 23 & 29 \\
\hline Oropharynx & 23 & 29 \\
\hline Hypopharynx & 17 & 21 \\
\hline Larynx & 6 & \\
\hline Other & 10 & 13 \\
\hline \multicolumn{3}{|l|}{$R T$ indications } \\
\hline ENE with PSM & 29 & 37 \\
\hline ENE without PSM & 25 & 31 \\
\hline PSM & 18 & 23 \\
\hline Positive $\mathrm{LN} \geq 3$ & 4 & \\
\hline pT4 & 3 & \\
\hline \multicolumn{3}{|l|}{$P T$-classification } \\
\hline 0 & 5 & 6 \\
\hline 1 & 10 & 13 \\
\hline 2 & 30 & 38 \\
\hline 3 & 15 & 19 \\
\hline 4 & 19 & 24 \\
\hline \multicolumn{3}{|l|}{$P N$-classification } \\
\hline 0 & 11 & 14 \\
\hline 1 & 15 & 19 \\
\hline $2 \mathrm{a}$ & 11 & 14 \\
\hline $2 b$ & 27 & 34 \\
\hline $2 \mathrm{c}$ & 5 & 6 \\
\hline 3 & 10 & 13 \\
\hline
\end{tabular}

ENE extracapsular nodal extension, PSM positive surgical margin, $L N$ lymph nodes
Pretreatment evaluation included a medical history, physical examination, panendoscopy and biopsy, computed tomography (CT) and/or magnetic resonance imaging (MRI) of the head and neck region in all cases. Additional diagnostic procedures for distant metastases, including CT scan of the chest, liver ultrasound, bone scintigraphy, and/ or, more recently, positron emission tomography were only performed if clinically indicated. $\mathrm{T}$ - and $\mathrm{N}$-classification were assigned according to the staging system of the International Union against Cancer (UICC) $2002 .^{8}$

\section{Statistical Methods}

Overall survival (OS), disease-free survival (DFS), and cancer-specific survival (CSS) rates as well as actuarial locoregional control (LRC) rates were calculated using the product-limit method. ${ }^{9}$ Time to any event was measured from the date of pathological diagnosis. The events were death (all causes) for OS, head and neck cancer-related mortality for CSS, and death (all causes) or relapse for DFS. For the LRC rate, the event consisted of local and/or regional relapse. Confidence intervals (CI) were calculated from standard errors. Differences between groups were assessed using the log-rank test. ${ }^{10}$ Multivariate analyses were done using the Cox stepwise-regression analysis to determine the independent contribution of each prognostic factor. $^{11}$

\section{RESULTS}

All patients underwent primary curative surgery. PORT was indicated for positive surgical margins $(n=18)$ or for pT4 tumors $(n=3)$ in $21(27 \%)$ patients, or because of extranodal infiltration with $(n=29)$ or without $(n=25)$ positive surgical margins in $54(68 \%)$ patients. Four patients $(5 \%)$ with three or more positive nodes were also included. Total dose to the spinal cord was limited to 46 Gy. Median RT duration was 39 days (range 3559 days). The interval between surgery and radiotherapy was $\leq 42$ days in 51 patients $(65 \%)$ and $>42$ days in 28 patients $(35 \%)$.

Conformal three-dimensional (3D)-RT planning was used in all patients. Patient immobilization was accomplished with individualized thermoplastic masks. The boost volume (66 Gy) consisted of the clinical target volume (CTV1), which was defined according to the presurgical location of the primary tumor and its nodal extension including the entire surgical bed; and the planning target volume (PTV1) included a 5-mm margin around the CTV1 in three dimensions. This volume was treated every Friday afternoon during the first 5 weeks, and daily during the first 3 days of the sixth week. The initial treatment volume 
(PTV2; 50 Gy), which was treated once daily during the first 5 weeks, consisted of the boost volume and all nodal areas at risk of subclinical malignant disease (CTV2) including a 5-mm margin around the CTV2 in three dimensions. The irradiation source was either a telecobalt unit or a linear accelerator using 6-MV photons and electrons.

Pre- and postoperative $\mathrm{Hb}$ levels were collected in all patients. While no information was available concerning the amount of blood loss during surgery, none of the patients required blood transfusion due to surgery. In this study, Hb cut-off value was considered $<120 \mathrm{~g} / \mathrm{l}$ in women and $<130 \mathrm{~g} / \mathrm{l}$ in men. The median $\mathrm{Hb}$ level before surgery was $138 \mathrm{~g} / \mathrm{l}$ (range 98-174 g/l), and after surgery $109 \mathrm{~g} / \mathrm{l}$ (range $74-161 \mathrm{~g} / \mathrm{l}$ ). The distribution of the $\mathrm{Hb}$ value according to gender is shown in Table 2. A median decrease of $24 \mathrm{~g} / \mathrm{l}$ of $\mathrm{Hb}$ (quartile values 9 and $38 \mathrm{~g} / \mathrm{l}$ ) was observed between pre- and postoperative $\mathrm{Hb}$ levels (range $-44-68 \mathrm{~g} / \mathrm{l})$.

After median follow-up period of 52 months (range $12-95$ months), 39 of 79 patients were alive with $(n=1)$ or without $(n=38)$ evidence of disease. Median time to locoregional relapse $(n=16)$ was 14 months (range 4-68 months). Median time to distant metastases $(n=19)$ was 16 months (range 3-48 months).

The 2- and 4-year OS, CSS, and DFS rates were 65\% (95\% CI: $54-76 \%$ ) and $51 \%$ (95\% CI: $39-63 \%), 71 \%$ (95\% CI: $60-82 \%$ ), and $60 \%$ (95\% CI: $48-72 \%$ ), and $61 \%$ (95\% CI: 49-73\%) and 48\% (95\% CI: 35-60\%), respectively (Fig. 1). The 2- and 4-year actuarial LRC probability was 94\% (95\% CI: 88-100\%) and 79\% (95\% CI: 69-89\%), respectively. Distant metastases were observed in 19 (24\%) patients, with the probability of being without distant metastases at 2 and 4 years being 79\% (95\% CI: 69-89\%) and $67 \%$ (95\% CI: 55-79\%), respectively.

In univariate analyses, gender, age, tumor site, $\mathrm{Hb}$ values before and after surgery, pT- and pN-classification, presence of ENE, interval between surgery and PORT, total RT time, and amount of $\mathrm{Hb}$ decrease were analyzed.

TABLE 2 Hemoglobin status in 79 patients

\begin{tabular}{|c|c|c|}
\hline & Preoperative & Postoperative \\
\hline Median (g/l) & 138 & 109 \\
\hline \multirow[t]{2}{*}{ Range (g/l) } & $98-174$ & $74-161$ \\
\hline & Number (\%) & Number (\%) \\
\hline \multicolumn{3}{|l|}{ Men $(g / 1)$} \\
\hline$<130$ & $21(27)$ & $48(61)$ \\
\hline$\geq 130$ & $41(52)$ & $14(18)$ \\
\hline \multicolumn{3}{|l|}{ Women (g/l) } \\
\hline$<120$ & $4(5)$ & $11(14)$ \\
\hline$\geq 120$ & $13(16)$ & $6(7)$ \\
\hline
\end{tabular}

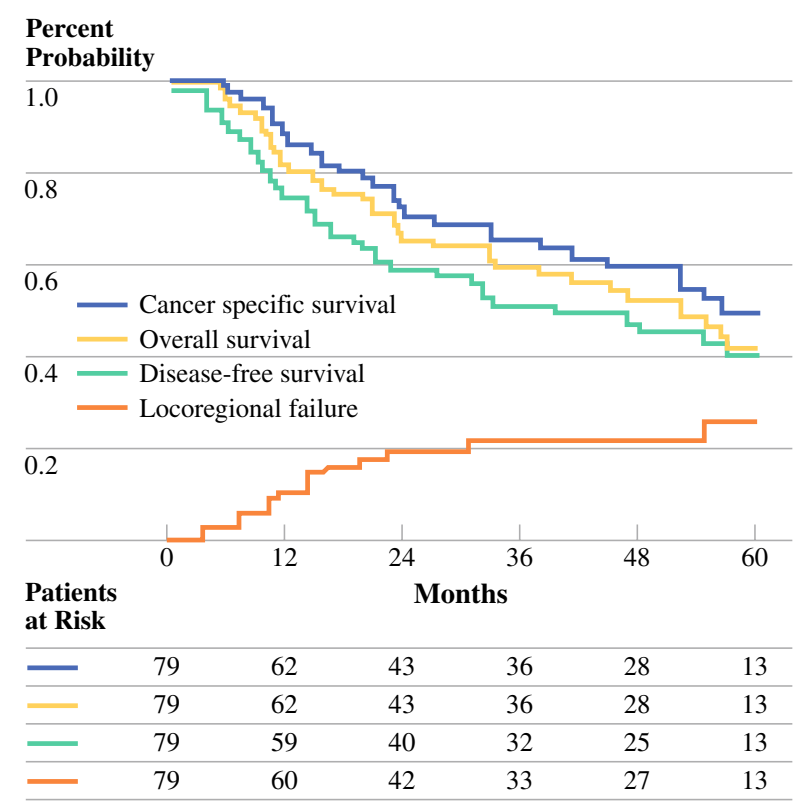

FIG. 1 Probability of cancer-specific survival (dashed line), overall survival (solid line), disease-free survival (dotted line), and locoregional failure (dashed/dotted line) in 79 patients treated with accelerated postoperative radiotherapy

T-classification, ENE, and decreasing $\mathrm{Hb}$ more than $38 \mathrm{~g} / \mathrm{l}$ were statistically significant prognosticators on univariate analyses (Table 3; Fig. 2). T-classification and ENE remained independently significant in multivariate analyses (Table 4) for OS, DFS, and CSS. Hb decrease more than $38 \mathrm{~g} / \mathrm{l}$ was also an independent factor influencing the CSS (Table 4). No factor influencing the LRC was found in either univariate or multivariate analyses.

There was no correlation between $\mathrm{T}$ - or N-classification and the amount of $\mathrm{Hb}$ decrease following surgery (9 of 45 patients with $\mathrm{T} 1-\mathrm{T} 2$ tumors and $\mathrm{Hb}$ decrease $\leq 38 \mathrm{~g} / \mathrm{l}$ versus 9 of 34 patients with $\mathrm{T} 3-\mathrm{T} 4$ tumors and $\mathrm{Hb}$ decrease $>38 \mathrm{~g} / \mathrm{l}, P=0.50$; and 9 of 26 patients with N0$\mathrm{N} 1$ disease and $\mathrm{Hb}$ decrease $\leq 38 \mathrm{~g} / \mathrm{l}$ versus 9 of 53 with $\mathrm{N} 2-\mathrm{N} 3$ disease and $\mathrm{Hb}$ decrease $>38 \mathrm{~g} / \mathrm{l}, P=0.09$ ).

\section{DISCUSSION}

Locoregional control is currently the most important issue in the treatment of LAHNC, and locoregional recurrence translates directly into poor overall survival. ${ }^{12,13}$ Several treatment-specific factors (e.g., total radiation dose, overall treatment time, interval between surgery, and RT) and patient-specific characteristics (e.g., age, sex, performance status, anemia, stage, ENE, and surgical margin) are known to influence the probability of local tumor control by RT alone or with surgery. Patients with positive surgical margins, perineural invasion, lymph node involvement, presence of ENE constitute a subgroup of patients with 
TABLE 3 Univariate analyses

\begin{tabular}{|c|c|c|c|c|c|c|c|c|c|c|c|c|c|}
\hline & $n$ & $\begin{array}{l}4-y r \\
\text { OS }\end{array}$ & $\begin{array}{l}95 \% \\
\mathrm{CI}\end{array}$ & $\begin{array}{l}P- \\
\text { value }\end{array}$ & $\begin{array}{l}4-y r \\
\text { DFS }\end{array}$ & $\begin{array}{l}95 \% \\
\mathrm{CI}\end{array}$ & $\begin{array}{l}P \text { - } \\
\text { value }\end{array}$ & $\begin{array}{l}4-y r \\
\text { CSS }\end{array}$ & $\begin{array}{l}95 \% \\
\mathrm{CI}\end{array}$ & $\begin{array}{l}P- \\
\text { value }\end{array}$ & $\begin{array}{l}4-y r \\
\text { LRC }\end{array}$ & $\begin{array}{l}95 \% \\
\mathrm{CI}\end{array}$ & $\begin{array}{l}P \text { - } \\
\text { value }\end{array}$ \\
\hline All patients & 79 & 51 & $39-63$ & & 48 & $35-60$ & & 60 & $48-72$ & & 79 & $69-89$ & \\
\hline \multicolumn{14}{|l|}{ Gender } \\
\hline Female & 17 & 68 & $44-90$ & 0.38 & 62 & $37-87$ & 0.35 & 77 & $53-100$ & 0.29 & 71 & $46-96$ & 0.65 \\
\hline Male & 62 & 48 & $34-62$ & & 44 & $30-58$ & & 56 & $42-70$ & & 81 & $70-92$ & \\
\hline \multicolumn{14}{|l|}{ Age (years) } \\
\hline$<60$ & 43 & 50 & $42-68$ & 0.35 & 46 & $28-64$ & 0.47 & 54 & $38-70$ & 0.54 & 76 & $62-90$ & 0.74 \\
\hline$\geq 60$ & 36 & 52 & $34-70$ & & 49 & $31-67$ & & 68 & $50-86$ & & 84 & $71-97$ & \\
\hline \multicolumn{14}{|l|}{ Tumor site } \\
\hline Oral cavity & 23 & 59 & $39-79$ & 0.93 & 47 & $25-69$ & 0.86 & 65 & $45-85$ & 0.99 & 86 & $71-100$ & 0.57 \\
\hline Oropharynx & 23 & 49 & $28-70$ & & 45 & $24-66$ & & 56 & $34-78$ & & 72 & $53-91$ & \\
\hline Larynx/hypo. & 23 & 50 & $25-75$ & & 50 & $27-73$ & & 57 & $31-83$ & 7 & 3 & 49-97 & \\
\hline Other & 10 & 50 & $15-85$ & & 50 & $15-85$ & & 57 & $20-94$ & & 83 & $53-100$ & \\
\hline \multicolumn{14}{|l|}{ T-classification } \\
\hline pT1-2 & 45 & 57 & $41-73$ & 0.03 & 59 & $43-75$ & 0.07 & 63 & $47-79$ & 0.06 & 83 & $72-94$ & 0.51 \\
\hline pT3-4 & 34 & 44 & $26-62$ & & 30 & $12-48$ & & 55 & $36-74$ & & 71 & $52-90$ & \\
\hline \multicolumn{14}{|l|}{$N$-classification } \\
\hline pN0-1 & 26 & 55 & $33-77$ & 0.35 & 46 & $24-68$ & 0.44 & 69 & $50-88$ & 0.40 & 75 & $57-93$ & 0.62 \\
\hline $\mathrm{pN} 2-3$ & 53 & 49 & $35-63$ & & 48 & $34-52$ & & 55 & $39-71$ & & 81 & $69-93$ & \\
\hline \multicolumn{14}{|l|}{$E N E$} \\
\hline No & 26 & 73 & $54-92$ & 0.03 & 57 & $35-79$ & 0.04 & 87 & $73-100$ & 0.01 & 87 & $73-100$ & 0.16 \\
\hline Yes & 53 & 40 & $26-54$ & & 38 & $23-53$ & & 45 & $29-61$ & & 74 & $60-88$ & \\
\hline \multicolumn{14}{|c|}{$\begin{array}{l}\text { Surgery-RT interval } \\
\quad \text { (days) }\end{array}$} \\
\hline$\leq 42$ days & 51 & 50 & $34-66$ & 0.96 & 47 & $31-63$ & 0.92 & 55 & $37-73$ & 0.59 & 79 & $67-91$ & 0.94 \\
\hline$>42$ days & 28 & 53 & $37-69$ & & 49 & $30-68$ & & 68 & $48-88$ & & 79 & $62-96$ & \\
\hline \multicolumn{14}{|c|}{$R T$ duration (days) } \\
\hline$\leq 39$ days & 54 & 49 & $35-63$ & 0.58 & 43 & $29-57$ & 0.46 & 54 & $38-70$ & 0.15 & 76 & $63-89$ & 0.58 \\
\hline$>39$ days & 25 & 57 & $35-72$ & & 57 & $35-79$ & & 73 & $53-93$ & & 84 & $68-100$ & \\
\hline \multicolumn{14}{|c|}{$\mathrm{Hb}(\mathrm{g} / \mathrm{l})$ before surgery } \\
\hline Low $^{\mathrm{a}}$ & 25 & 56 & $34-78$ & 0.95 & 53 & $31-75$ & 0.97 & 65 & $42-88$ & 0.75 & 86 & $68-100$ & 0.33 \\
\hline High $^{\mathrm{b}}$ & 54 & 50 & $43-57$ & & 47 & $33-61$ & & 58 & $44-72$ & & 75 & $63-87$ & \\
\hline \multicolumn{14}{|c|}{$\mathrm{Hb}(\mathrm{g} / \mathrm{l})$ after surgery } \\
\hline Low $^{\mathrm{a}}$ & 59 & 53 & $39-67$ & 0.89 & 47 & $33-61$ & 0.89 & 60 & $56-74$ & 0.78 & 79 & $67-91$ & 0.95 \\
\hline $\operatorname{High}^{\mathrm{b}}$ & 20 & 46 & $23-69$ & & 46 & $23-69$ & & 59 & $46-82$ & & 77 & $57-97$ & \\
\hline \multicolumn{14}{|c|}{ Hb decrease $(g / l)$} \\
\hline Median $\leq 24$ & 43 & 60 & $44-76$ & 0.15 & 56 & $40-72$ & 0.32 & 72 & $56-88$ & 0.04 & 80 & $66-94$ & 0.94 \\
\hline$>24$ & 36 & 41 & $23-59$ & & 37 & $19-55$ & & 46 & $28-64$ & & 77 & $62-92$ & \\
\hline Quartile $\leq 38$ & 61 & 61 & $47-75$ & 0.008 & 56 & $42-70$ & 0.02 & 70 & $56-84$ & 0.005 & 80 & $69-91$ & 0.59 \\
\hline$>38$ & 18 & 16 & $0-36$ & & 17 & $0-36$ & & 24 & $0-50$ & & 74 & $52-96$ & \\
\hline
\end{tabular}

${ }^{\mathrm{a}}$ Low $<120 \mathrm{~g} / \mathrm{l}$ in women and $<130 \mathrm{~g} / \mathrm{l}$ in men

${ }^{\mathrm{b}}$ High $\geq 20 \mathrm{~g} / \mathrm{l}$ in women and $\geq 130 \mathrm{~g} / \mathrm{l}$ in men

$O S$ overall survival, DFS disease-free survival, $C S S$ cancer-specific survival, $L R C$ locoregional control, $C I$ confidence interval, $R T$ radiotherapy, ENE extracapsular nodal extension

high risk of locoregional relapse. ${ }^{14-18}$ Besides all of these prognostic factors, numerous reports have pointed out the prognostic value of anemia and the adverse effects of tumor hypoxia on the efficacy of anticancer treatments in recent years, indicating that decreased radiosensitivity resulting from tumor hypoxia was the most likely explanation. ${ }^{1-4,19}$ Recently Rades et al. analyzed 153 LAHNC patients; they found performance status, stage, surgery, 


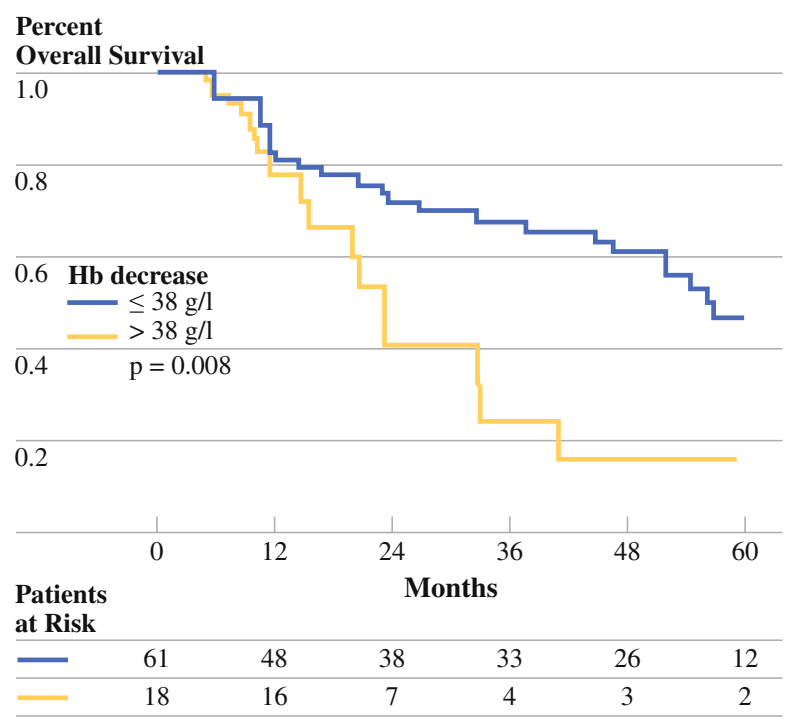

FIG. 2 Overall survival according to hemoglobin $(\mathrm{Hb})$ decrease following surgery. Solid line represents patients with $\mathrm{Hb}$ decrease $\leq 38 \mathrm{~g} / \mathrm{l}$, and dashed line patients with $\mathrm{Hb}$ decrease $>38 \mathrm{~g} / \mathrm{l}$ (logrank test, $P=0.008$ )

pre-radiotherapy $\mathrm{Hb}$ level, and interruptions during RT $>1$ week were important prognostic factors for outcome of radiochemotherapy treatment. ${ }^{20}$ Three-year LRC was $46 \%$ and $75 \%$ in the $\mathrm{Hb}<12 \mathrm{~g} / \mathrm{dl}$ and $\mathrm{Hb} \geq 12$ groups.

As reported in the literature, in this study univariate and multivariate analyses showed that tumor stage and ENE were significant prognostic factors for OS, DFS, and CSS (Table 3). Besides all of these factors, univariate analyses showed that $\mathrm{Hb}$ decrease more than $38 \mathrm{~g} / \mathrm{l}$ during surgery was also a prognostic factor. Four-year DFS, OS, and CSS were $56 \%, 61 \%$, and $70 \%$ in patients with $\mathrm{Hb}$ decreased $38 \mathrm{~g} / \mathrm{l}$ or less compared with $16 \%, 16 \%$, and $24 \%$ in patients with $\mathrm{Hb}$ decreased more than $38 \mathrm{~g} / \mathrm{l}$. However, presurgery or pre-RT $\mathrm{Hb}$ value did not show any significant influence on DFS, OS, or CCS (Table 3).

During major surgery, substantial blood loss is possible, varying between mean values of 500 and $1,500 \mathrm{ml}$, and amount of this loss may be depending on disease stage, tumor size, or any other surgical parameters. ${ }^{2,21}$ In our study, neither tumor size nor nodal status was correlated with the $\mathrm{Hb}$ decrease. Twenty percent of patients with $\mathrm{T} 1-$ $\mathrm{T} 2$ tumors had an $\mathrm{Hb}$ decrease of $\leq 38 \mathrm{~g} / \mathrm{l}$, whereas $26 \%$ of the patients with T3-T4 an $\mathrm{Hb}$ decrease of $>38 \mathrm{~g} / \mathrm{l}$.

Confirming explanations might be based on radiobiological theories. Tumor hypoxia may induce proteomic and genomic changes, and they may result in clinically more aggressive tumors with increased potential of metastases through cellular process. ${ }^{22}$ Hypoxia induces the expression of various angiogenic cytokines [vascular endothelial growth factor (VEGF), basic fibroblast growth factor (bFGF), interleukin-8 (IL-8), tumor necrosis factor (TNF), etc.], responsible in the course of various signal transduction cascades for the proliferation, migration, and differentiation of the endothelial cells responsible for the development of neovasculature in a tumor. ${ }^{23}$ Furthermore, hypoxia gives rise to inhibition of cellular proliferation by an accumulation of cells in phase G0 of the cell cycle. It reduces cytotoxicity, induces hypoxic stress proteins, lowers the apoptotic potential, and causes tissue acidosis. ${ }^{24}$ All these factors released under hypoxic conditions may result in a malignant phenotype of residual tumor cells left after surgery; and may, therefore, lead to a more aggressive regrowth of these cells resulting in recurrences.

A number of clinical studies aimed to increase the outcome by increasing the $\mathrm{Hb}$ level by either blood transfusions or recombinant erythropoietin (rEPO). There is, currently, no clear evidence that correction of anemia improves prognosis. Henke and colleagues prospectively compared anemic head and neck cancer patients receiving definitive RT or PORT with or without rEPO treatment. ${ }^{25}$ They reported that rEPO treatment corrected hemoglobin levels, however, had negative impact on locoregional cancer control and survival. Recently, Overgaard et al. presented the results of the DAHANCA 10 randomized trial. ${ }^{26}$ In this study, 515 patients with $\mathrm{Hb}$ values below $9.0 \mathrm{mmol} / \mathrm{l}(14.0 \mathrm{~g} / \mathrm{dl})$ treated with definitive RT were randomized to receive darbopoietin together with accelerated RT. They observed a significant correction of the $\mathrm{Hb}$ level with darbopoietin in patients with LAHNC resulting, however, in a significantly poorer locoregional control after

TABLE 4 Multivariate analyses

\begin{tabular}{|c|c|c|c|c|c|c|c|c|}
\hline \multirow{2}{*}{ Parameter } & \multicolumn{2}{|c|}{ Overall survival } & \multicolumn{2}{|c|}{ Disease-free survival } & \multicolumn{2}{|c|}{ Cancer-specific survival } & \multicolumn{2}{|c|}{ Locoregional control } \\
\hline & $\mathrm{RR}$ & $P$-value & $\mathrm{RR}$ & $P$-value & $\mathrm{RR}$ & $P$-value & $\mathrm{RR}$ & $P$-value \\
\hline $\begin{array}{l}\text { T-classification (pT3-4 } \\
\text { versus pT1-2) }\end{array}$ & 1.47 & 0.02 & 1.38 & 0.05 & 1.49 & 0.04 & NS & \\
\hline $\begin{array}{l}\text { Extranodal extension } \\
\text { (yes versus no) }\end{array}$ & 1.59 & 0.01 & 1.52 & 0.02 & 1.82 & 0.005 & NS & \\
\hline $\begin{array}{l}\text { Hb decrease }(\mathrm{g} / \mathrm{l}) \\
\quad(>38 \text { versus } \leq 38)\end{array}$ & 1.39 & 0.07 & 1.35 & 0.09 & 1.49 & 0.05 & NS & \\
\hline
\end{tabular}

$R R$ risk ratio, $N S$ not significant 
RT ( $56 \%$ versus $69 \%, P=0.02$ ). The use of darbopoietin resulted in an increased $\mathrm{Hb}$ value in more than $91 \%$ of the patients. However, there was no significant difference in terms of overall survival (38\% versus $51 \%, P=0.08$ ).

Primary surgery and PORT is a traditional approach for operable LAHNC patients. Success of the RT may be compromised by the presence of demonstrably unfavorable factors. Surgical procedures and reconstruction frequently result in high intraoperative blood loss. This study shows that perioperative $\mathrm{Hb}$ decrease may influence the outcome of the patients who are candidates for PORT. Given negative anemia-correction studies using rEPO, strategies to prevent perioperative $\mathrm{Hb}$ decrease should focus on limiting blood loss during surgery. Alternative intraoperative techniques to minimize bleeding, intraoperative or postoperative blood transfusion, and investigation of other pharmacologic agents are warranted.

\section{REFERENCES}

1. Tarnawski R, Skladowski K, Maciejewski B. Prognostic value of hemoglobin concentration in radiotherapy for cancer of supraglottic larynx. Int J Radiat Oncol Biol Phys. 1997;38:1007-11.

2. Scott SN, Boeve TJ, McCulloch TM, Fitzpatrick KA, Karnell LH. The effects of epoetin alfa on transfusion requirements in head and neck cancer patients: a prospective randomised, placebo-controlled study. Laryngoscope. 2002;112:1221-9.

3. Overgaard J, Horsman MR. Modification of hypoxia-induced radioresistance in tumors by the use of oxygen and sensitizers. Semin Radiat Oncol. 1996;6:10-21.

4. Vaupel P, Mayer A, Höckel M. Impact of hemoglobin levels on tumor oxygenation: the higher, the better? Strahlenther Onkol. 2006;182:63-71.

5. Lee WR, Berkey B, Marcial V, Fu KK, Cooper JS, Vikram B, et al. Anemia is associated with decreased survival and increased locoregional failure in patients with locally advanced head and neck carcinoma: a secondary analysis of RTOG 85-27. Int $J$ Radiat Oncol Biol Phys. 1998;42:1069-75.

6. Brizel DM, Albers ME, Fisher SR, Scher RL, Richtsmeier WJ, Hars V, et al. Hyperfractionated irradiation with or without concurrent chemotherapy for locally advanced head and neck cancer. N Engl J Med 1998; 338:1798-1804.

7. Nordsmark M, Bentzen SM, Rudat V, Brizel D, Lartigau E, Stadler P, et al. Prognostic value of tumor oxygenation in 397 head and neck tumors after primary radiation therapy: an international multi-center study. Radiother Oncol. 2005;77:18-24.

8. Sobin LH, Wittekind C. International Union Against Cancer (UICC): TNM classification of malignant tumors, 6th ed. New York: Wiley-Liss; 2002. p 19-47.

9. Kaplan EL, Meier P. Non parametric estimation from incomplete observations. J Am Stat Assoc. 1958;53:457-81.

10. Peto P, Pike MC, Armitage P, Breslow NE, Cox DR, Howard SV, et al. Design and analysis of randomised clinical trials requiring prolonged observation of each patients: part II. $\mathrm{Br} J$ Cancer. 1977;35:1-39.

11. Cox DR. Regression models and life tables. $J R$ Stat Soc. 1972;34:187-200.
12. Zouhair A, Azria D, Pasche P, Stupp R, Chevalier J, Betz M, et al. Accelerated postoperative radiotherapy with weekly concomitant boost in patients with locally advanced head and neck cancer. Radiother Oncol. 2004;70:183-8.

13. Bernier J, Domenge C, Ozsahin M, Matuszewksa K, Lefèbvre JL, Greiner RH, et al. Postoperative irradiation with or without concomitant chemotherapy for locally advanced head and neck cancer. N Engl J Med. 2004;350:1945-52.

14. Mirimanoff RO, Wang CC, Doppke KP. Combined surgery and postoperative radiation therapy for advanced laryngeal and hypopharyngeal carcinomas. Int J Radiat Oncol Biol Phys. 1985; 11:499-504.

15. Carter RL, Tanner NSB, Clifford P, Shaw HJ. Perineural spread in squamous cell carcinomas of the head and neck: a clinicopathological study. Clin Otolaryngol. 1979:4:271-81.

16. Olsen KD, Caruso M, Foote RL, Stanley RJ, Lewis JE, Buskirk $\mathrm{SJ}$, et al. Primary head and neck cancer: histopathologic predictors of recurrence after neck dissection in patients with lymph node involvement. Arch Otolaryngol Head Neck Surg. 1994; 120:1370-4.

17. Johnson JT, Barnes EL, Myers EN, Schramm VL Jr, Borochovitz D, Sigler BA. The extracapsular spread of tumors in cervical node metastasis. Arch Otolaryngol. 1981;107:725-9.

18. Bernier J, Cooper JS, Pajak TF, van Glabbeke M, Bourhis J, Forastiere A, et al. Defining risk levels in locally advanced head and neck cancers: a comparative analysis of concurrent postoperative radiation plus chemotherapy trials of the EORTC (\#22931) and RTOG (\#9501). Head Neck. 2005;27:843-50.

19. Ozsahin M, Azria D, Beer K, Mirimanoff RO, Zouhair A. External radiotherapy and anemia treatment: state of the art. Swiss Med Wkly. 2005;135:4-10.

20. Rades D, Stoehr M, Kazic N, Hakim SG, Walz A, Schild SE, et al. Locally advanced stage IV squamous cell carcinoma of the head and neck: impact of pre-radiotherapy hemoglobin level and interruptions during radiotherapy. Int J Radiat Oncol Biol Phys. 2008;70:1108-14.

21. Clark JR, McCluskey SA, Hall F, Lipa J, Neligan P, Brown D, et al. Predictors of morbidity following free flap reconstruction for cancer of the head and neck. Head Neck. 2007;29:1090-1101.

22. Höckel MP, Vaupel P. Biological consequences of tumor hypoxia. Semin Oncol. 2001;28(2 suppl 8):36-41.

23. Richard DE, Berra E, Pouyssegur J. Angiogenesis: how a tumor adapts to hypoxia. Biochem Biophys Res Commun. 1999:266: 718-22.

24. Double-blind, placebo-controlled study of the therapeutic use of recombinant human erythropoietin for anemia associated with chronic renal failure in predialysis patients. The US Recombinant Human Erythropoietin Predialysis Study Group. Am J Kidney Dis. 1991;18:50-9.

25. Henke M, Laszig R, Rübe C, Schäfer U, Hasse KD, Schilcher B, et al. Erythropoietin to treat head and neck cancer patients with anemia undergoing radiotherapy: randomised, double-blind, placebo-controlled trial. Lancet 2003;362:1255-60.

26. Overgaard J, Hoff C, Sand Hansen H, Specht L, Overgaard M, Grau C, et al. Randomized study of the importance of Novel Erythropoiesis Stimulating Protein (Aranesp) for the effect of radiotherapy in patients with primary squamous cell carcinoma of the head and neck (HNSCC): the Danish Head and Neck Cancer Group DAHANCA 10 randomized trial. Eur J Cancer. 2007; 5(suppl):7. 